\title{
The Study on the Importance and Development Strategy of College Students' Music Quality Education
}

\author{
Tong-xiang Zheng \\ Preschool Education Institute \\ Xuanhua Science\& Technology Vocational College \\ Xuanhua, China
}

\begin{abstract}
As the main position of quality education, colleges and universities play an irreplaceable role in cultivating comprehensive development talent engineering. Music quality education is the important content of implementing quality education and realizing the talents training goal of all-round development. This paper will analyze the importance of carrying out music quality education to college students, and study the problems existing in music quality education. Finally, the corresponding reform and development strategy will be put forward to provide reference basis for music quality education in our country's general colleges.
\end{abstract}

Keyword: college students; music quality education; importance; development strategy

\section{INTRODUCTION}

The advent of information age and the global multicultural era make the society need more and more high-quality and innovative talents ${ }^{[1]}$. With the deepening of education reform, the outlook on talents and quality is undergoing a fundamental shift, which means the transformation form narrow professional education to comprehensive quality education ${ }^{[2]}$. College students are the main force of our country's economy and modern development in the new century, and also the future and hope of the motherland. Music quality education is an essential part of college students' scientific and cultural quality education ${ }^{[3]}$. It has a unique function of improving college students' humanistic quality, promoting the mastery of scientific knowledge, improving ability and developing their personality. Strengthening college music education has a great significance to popularize and implement the quality education ${ }^{[4]}$.

\section{The importance of college students' music quality education}

\subsection{Concept of music quality education}

Music quality education means that colleges fully motivate students' artistic potential through music education, improve the students' knowledge structure, and make the students cultivating their taste. Music quality education can improve students' all-round development in the aesthetic, appreciation, understanding and expression process of music activities, and promote students' all-round development education. Music quality education's aims at comprehensively implementing party's education policy, and developing intelligent and creative all-round development high-quality talents ${ }^{[5]}$.

\subsection{The characteristics of general colleges' music quality education}

Since entering the $21^{\text {st }}$ century, with the development and deepening of quality education, colleges' music quality education is attaching more and more attention, and college students' music accomplishment is becoming an important aspect of measuring students' comprehensive quality. Accurately grasping the characteristics of colleges' music quality education has an important significance to make better education plan and develop quality education ${ }^{[4]}$.

(1) Comprehensiveness and fundamentality.

The popularity of music quality education in colleges and universities should cover the various departments, and make every students receive the corresponding training of music quality education.

(2) The purity of music content.

In order to achieve moral education and aesthetic education, which is a goal of quality education, the music works should have the characteristic of purity. Only the pure music can purify people's soul, improve people's culture, make people's spirit get sublimated, and suit the requirements of quality education.

(3) People-oriented

People-oriented is the essence of science and education development. The primary task of implementing music quality education is to arouse students' interest in music and hobbies. The forms and styles should not be too single. Students' main position should be reflected in the choice of teaching content, design of teaching forms, and establishment of evaluation standard, which reflect truly people-oriented.

(4) Pay attention to the process of music aesthetics

From the purpose of music quality education, we can see that in order to improve the students' comprehension ability, we must pay more attention to cultivating students' music 
appreciation. Cultivating the students music comprehension ability in music appreciation, and analyzing music works in the relevant situations, the students' aesthetic ability will be improved.

\subsection{The importance of implementing music quality education in Chinese general colleges}

Music quality education is an important part in quality education that we strongly advocate. Compared with other kinds of education, because of its nature and characteristics, music quality education lacks the corresponding effectiveness, and its effect is not as prominent as other kinds of educations'. But in terms of the individuals' all-round development, peoples' overall quality, and individual sentiment' cultivation, music education plays non-fungible position.

(1) Music quality education can adjust the students' mood.

Music can weaken individuals' negative emotion, and even transform it into positive emotions. Music therapy is the best proof. In foreign countries, music has been introduced into the treatment of patients with depression and mania. The specific approach is to give light music to pressed patients, and quiet music to rage patients, which proves certain effect to transfer patients' mood. In our country, more and more people know and use music therapy. In today's society, competition is intense, the pressure is huge, and the social relation is complex. College students are under more pressure of employment, education, etc. Under various pressures, their psychological endurance becomes increasingly fragile, and music can improve their mood, so that they can move on.

Music can also relieve people's fatigue, and improve their work efficiency and quality. According to psychologist scientific experiments, music can directly act on humans' hypothalamus, making them relaxation and leisure. This can effectively relieve people's nervous mentality. In the fatigue study, a joyful melody, a sweet song, is very helpful to people's physical and mental recovery.

(2) Music education plays an important role to promote students' aesthetic education.

Cultivating students' awareness of beauty is one of the important tasks of college students' art education to enhance students' aesthetic ability. In the aspect of music quality education, students' aesthetic ability and level are improved through several levels, such as cultivating the students' music perception, music appreciation, music imagination and creativity. An individual's need to music is a kind of need for beauty. Music appreciation is also a kind of education for beauty, and is a kind of active enjoyment, producing happy experience in the process of appreciation. In such situation, students' enthusiasm will be fully mobilized. So it is easy to find that it is a feasible and effective way to strengthen students' aesthetic ability through improving students' music quality and strengthening students' art quality.

(3) The promotion of music quality can promote the individual's intellectual development.

Person's intelligence is composed of all kinds of comprehensive ability, and the core is thinking ability. In addition, creative ability, imagination ability and communication ability are also the important part. Intelligence can be divided into general intelligence and special intelligence, according to which music intelligence belongs to special intelligence. And the development of special intelligence can promote the development of general intelligence, so as to improve the overall level of individual intelligence. More and more people have realized the importance of individual's music ability to creative. Many scientists have higher music ability. At present, many parents send their children to music classes and instrument classes, actually not only to learn music, but also to improve their children's intelligence and cultivate children's interest through music.

\section{The problems existing in the college student's music quality education}

\subsection{Colleges and universities don't pay enough attention to music quality education}

Many colleges, especially those to train professional talents and applied talents, don't have a clear understanding to students' comprehensive quality improvement and humanistic concern. To the important parts of quality education, music education doesn't pay enough attention. Thus cause the funds allocation for music education used for others artificially.

\subsection{Management system lags behind}

Currently, in Chinese general colleges, quiet a few doesn't set majors of music category related and doesn't recruit art examinee of music category. Therefore, some colleges and universities don't have music education specialized agency or rely on other administrative department. Since agency's authority is narrow, and its own development space is limited, it's difficult for music education to play its role. Music education institutions' narrow permissions directly affect the introduction of high-quality teachers, the procurement of high level equipment, and application for big projects. The more remarkably, almost all band, art troupe and chorus are directly affiliated to the students' affairs office and the communist youth league, rather than managed by music teachers understanding music. Over time, the corporate activities are at lower levels, which is not conductive for music education's scientific development.

\subsection{The weakness of teachers and the lack of teaching material}

Any education's going well is inseparable from the 
teachers' teaching, especially the music education, since its strong professional. For a long time, many colleges and universities, especially some higher vocational colleges don't pay enough attention to students' music education. The lack of music teachers is a good proof. Some colleges, especially those don't set majors of music category lack music teachers seriously. In some colleges, even only one or two teachers struggle to support the music education. There is also serious shortage of teacher training. Since the lack of teachers, teachers' teaching task is relatively large, and it is difficult to have time and experience to improve professional level and business ability.

\subsection{Systematic music curriculum system is lacked}

In most colleges and universities, music is just elective course, and the courses are set with great blindness. In the curriculum provision, there are more theory and less practice, and few participation and interactive opportunity, so the students are often in passive state. Since the music education content is short and monotonous, and the scope of knowledge is narrow, music education can't be digested with other subjects, such as cultural, history, etc. In some colleges, teaching environment is unreasonable, teaching mode is single, teaching method is obsolescence and music facilities is poor.

\section{The development strategy of college students' music quality education}

\subsection{Rich teaching contents}

General college students' music education teaching is a plane and a perspective to improve students' comprehensive quality. In the daily teaching, the teaching content should be enriched according to students' age characteristics, realistic need and education rule. According to the education level, colleges and universities can be divided into key university, general undergraduate, and higher technological school. According to the research direction, they can be divided into comprehensive university, humanities and social sciences universities and science technology universities. So in the practice, music education should be combined with other humanities and science, according to these realities and the students' present situation.

\subsection{Improve the management system}

In order to solve the problems existing in the current colleges' art education, system's power must be relied on. Only perfect management system can ensure music education smoothly. In terms of institutions, colleges should improve the music education institutions' position in the school, and independent it from other departments. The colleges should treat music education institutions and other departments equally. In the aspect of teachers' cultivation, colleges should not only actively provide training opportunities for music teachers, but also establish reasonable rules for music teachers' professional title appraisal, paper publishing, project application, etc.

\subsection{Strengthen teachers training}

In order to accelerate the depth development of art education in colleges and universities today, it is the inevitable requirement of improving the music education to strengthen the teaching staff's construction. Colleges should pay attention to the following points.

(1) Cultivating teachers' ideological and moral cultivation. Since the purpose of music quality education is to cultivate the students' comprehensive quality, the teachers should have good moral self-cultivation.

(2) Improving teachers' professional quality. Music teachers should have the solid basic knowledge of music major, systematic music subject knowledge and ability. In the face of non-music majors, teachers should have reasonable and rich teaching method to stimulate students' learning interest and use common language to teach students professional knowledge, such as Kodak's teaching methods, Orff teaching method, Suzuki method, etc.

\subsection{Strengthen the organic combination of the classroom music teaching and extracurricular music education activities.}

Colleges and universities should combine music lessons and extracurricular activities organically, making music quality education the developmental system engineering covering the whole university campus. Classroom teaching can adopt the method of combining compulsory courses and elective courses, not only teaching students basic knowledge, but also adapting to students' learning interest and social development demand. Extracurricular music education activities should proceed organically, designedly, and consistently. It is the key of improving music quality education to build colleges' music artistic atmosphere, and improve the students' interest in music. Building music artistic atmosphere can let students appreciate and feel the meaning of art, and improve their art appreciation ability.

\section{Conclusion}

Music education is an important way of promoting quality education overall development, and has a irreplaceable special role. Strengthening the general colleges' music education has a great significance to popularize and implement quality education. Based on the analysis the existing problems of colleges' music education, this paper puts forward some corresponding development strategies, hoping that colleges' music quality education can develop sustainably and healthily. 


\section{References}

[1] Tian Tiehan, Liu Jingang. The research on present situation and development strategy of college music quality education. Cultural and educational materials, 2008(3):219-220.

[2] Chang Liping. Construction about general colleges' music quality education courses. Central China Normal University, 2006.

[3] Zhang Xiaolei. The study of college students' music quality education based on innovative thinking cultivation. Dalian University of Technology, 2011,65.

[4] Wu Cuijing. Study of contemporary music quality education in general colleges. Hebei Normal University, 2011.

[5] Wang Zhihong. Research on current situation and countermeasures of general college students' music quality education in Hebei Province, Hebei normal university, 2009. 